\title{
Front Matter: Volume 6661
}

, "Front Matter: Volume 6661," Proc. SPIE 6661, Imaging Spectrometry XII, 666101 (27 September 2007); doi: 10.1117/12.774342

SPIE Event: Photonic Devices + Applications, 2007, San Diego, California, United SPIE. States 


\section{PROCEEDINGS OF SPIE}

\section{Imaging Spectrometry XII}

Sylvia S. Shen

Paul E. Lewis

Editors

28-29 August 2007

San Diego, California, USA

Sponsored and Published by

SPIE

Volume 6661

Proceedings of SPIE, 0277-786X, v. 6661 
The papers included in this volume were part of the technical conference cited on the cover and title page. Papers were selected and subject to review by the editors and conference program committee. Some conference presentations may not be available for publication. The papers published in these proceedings reflect the work and thoughts of the authors and are published herein as submitted. The publisher is not responsible for the validity of the information or for any outcomes resulting from reliance thereon.

Please use the following format to cite material from this book:

Author(s), "Title of Paper," in Imaging Spectrometry XII, edited by Sylvia S. Shen, Paul E. Lewis, Proceedings of SPIE Vol. 6661 (SPIE, Bellingham, WA, 2007) Article CID Number.

ISSN 0277-786X

ISBN 9780819468093

Published by

SPIE

P.O. Box 10, Bellingham, Washington 98227-0010 USA

Telephone +1 3606763290 (Pacific Time) · Fax +1 3606471445

SPIE.org

Copyright (C 2007, Society of Photo-Optical Instrumentation Engineers

Copying of material in this book for internal or personal use, or for the internal or personal use of specific clients, beyond the fair use provisions granted by the U.S. Copyright Law is authorized by SPIE subject to payment of copying fees. The Transactional Reporting Service base fee for this volume is $\$ 18.00$ per article (or portion thereof), which should be paid directly to the Copyright Clearance Center (CCC), 222 Rosewood Drive, Danvers, MA 01923. Payment may also be made electronically through CCC Online at copyright.com. Other copying for republication, resale, advertising or promotion, or any form of systematic or multiple reproduction of any material in this book is prohibited except with permission in writing from the publisher. The CCC fee code is $0277-786 \times / 07 / \$ 18.00$.

Printed in the United States of America.

Publication of record for individual papers is online in the SPIE Digital Library.

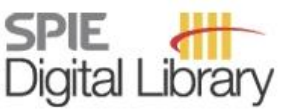

SPIEDigitallibrary.org

Paper Numbering: Proceedings of SPIE follow an e-First publication model, with papers published first online and then in print and on CD-ROM. Papers are published as they are submitted and meet publication criteria. A unique, consistent, permanent citation identifier (CID) number is assigned to each article at the time of the first publication. Utilization of CIDs allows articles to be fully citable as soon they are published online, and connects the same identifier to all online, print, and electronic versions of the publication. SPIE uses a six-digit CID article numbering system in which:

- The first four digits correspond to the SPIE volume number.

- The last two digits indicate publication order within the volume using a Base 36 numbering system employing both numerals and letters. These two-number sets start with 00, 01, 02, 03, 04, 05, $06,07,08,09,0 A, 0 B \ldots .0 Z$, followed by $10-1 Z, 20-2 Z$, etc.

The CID number appears on each page of the manuscript. The complete citation is used on the first page, and an abbreviated version on subsequent pages. Numbers in the index correspond to the last two digits of the six-digit CID number. 


\section{Contents}

vii Conference Committee

\section{SESSION $1 \quad$ SPECTROMETER DESIGN AND DEVELOPMENT}

666102 Advanced responsive tactically effective military imaging spectrometer (ARTEMIS): system overview and objectives (Invited Paper) [6661-01]

R. B. Lockwood, T. W. Cooley, R. M. Nadile, J. A. Gardner, P. S. Armstrong, A. M. Payton, T. M. Davis, S. D. Straight, Air Force Research Lab. (USA)

666103 Fourier methods of improving reconstruction speed for CTIS imaging spectrometers [6661-02]

N. Hagen, E. L. Dereniak, College of Optical Sciences, Univ. of Arizona (USA); D. T. Sass, U.S. Army TACOM (USA)

666104 Visible imaging spectro-polarimeter [6661-03]

C. Vandervlugt, N. Hagen, College of Optical Sciences, Univ. of Arizona (USA); R. Sampson, I Technology Applications (USA); E. Dereniak, College of Optical Sciences, Univ. of Arizona (USA); G. Gerhart, U.S. Army TACOM (USA)

666105 Compact spectrophotometer using polarization-independent liquid crystal tunable optical filters [6661-04]

E. Nicolescu, M. J. Escuti, North Carolina State Univ. (USA)

\section{SESSION 2 FOURIER TRANSFORM SPECTROMETER DESIGN AND DEVELOPMENT}

666106 State-of-the-art imaging Fourier-transform spectrometer with CCD camera (Invited Paper) [6661-05]

J. E. Genest, S. A. Roy, Univ. Laval (Canada); P. Dubois, Univ. Laval (Canada) and Telops Inc. (Canada); S. Potvin, Univ. Laval (Canada)

666107 Long wave focal plane array detector: development and performance assessment of an $8 \times 8$ Sterling cooled photovoltaic MCT detector module [6661-06]

L. Rochette, LR Tech (Canada); T. Smithson, Defence R\&D Canada (Canada);

R. Gurgenian, Fermionics Corp. (USA); G. St. Pierre, Gentec (Canada)

666108 SHIELDS: A battlespace Fraunhofer line discriminator for real-time aerosol cloud analysis [6661-09]

S. Watchorn, J. Noto, Scientific Solutions, Inc. (USA); J. Anderson, U. S. Army Engineer Research and Development Ctr. (USA); C. S. Sioris, Environment Canada (Canada); M. A. Migliozzi, Scientific Solutions, Inc. (USA)

666109 An interferometer for compact imaging spectrometer [6661-07] L. Moreau, F. Grandmont, S. Lantagne, R. Desbiens, M.-A. Soucy, ABB (Canada) 
6661 OA FTIR-based airborne spectral imagery for target interrogation [6661-08]

T. L. Smithson, D. St. Germain, D. Nadeau, Defence Research and Development Ctr.

Valcartier (Canada)

\section{SESSION $3 \quad$ IMAGING SYSTEMS AND COMPONENTS}

6661 OB Development of mercurous halide crystals for acousto-optic devices [6661-10] J.-S. Kim, S. B. Trivedi, J. Soos, Brimrose Corp. of America (USA); N. Gupta, Army Research Lab. (USA); W. Palosz, Brimrose Corp. of America (USA)

$66610 \mathrm{C}$ Occluded target viewing and identification high-resolution 2D imaging laser radar [6661-11]

R. J. Grasso, G. F. Dippel, K. D. Cecchetti, J. C. Wikman, D. P. Drouin, P. I. Egbert, BAE Systems (USA)

6661 OD Effect of light level and photon noise on hyperspectral target detection performance [6661-12]

T. Skauli, R. Ingebrigtsen, I. Kåsen, Norwegian Defense Research Establishment (Norway)

\section{SESSION 4 SPECTRAL DATA ANALYSIS TECHNIQUES}

$66610 E$ Linear unmixing using endmember subspaces and physics based modeling [6661-14]

D. Gillis, J. Bowles, Naval Research Lab. (USA); E. J. lentilucci, D. W. Messinger, Rochester Insitute of Technology (USA)

6661 OF Statistics-based endmember extraction algorithms for hyperspectral imagery [6661-15] S.-Y. Chu, C.-C. Wu, C.-I Chang, Univ. of Maryland, Baltimore County (USA)

6661 OG Synthetic data generation of high-resolution hyperspectral data using DIRSIG [6661-16] M. K. Jakubowski, Rochester Institute of Technology (USA) and Univ. of California, Berkeley (USA); D. Pogorzala, T. J. Hattenberger, S. D. Brown, J. R. Schott, Rochester Institute of Technology (USA)

$6661 \mathrm{OH}$ Atmospheric inversion in the presence of clouds: an adaptive ELM approach [6661-17] B. Bartlett, J. R. Schott, Rochester Institute of Technology (USA)

6661 Ol Unsupervised hyperspectral image classification [6661-18]

X. Jiao, C.-I Chang, Univ. of Maryland, Baltimore County (USA)

\section{SESSION $5 \quad$ SPECTRAL METHODOLOGIES AND APPLICATIONS}

6661 OJ Use of Lidar data to geometrically constrain radiance spaces for physics-based target detection [6661-19]

M. S. Foster, Rochester Institute of Technology (USA) and Air Force Institute of Technology (USA); J. R. Schott, D. W. Messinger, R. Raqueño, Rochester Institute of Technology (USA) 
6661 OK Preliminary assessment of the utility of airborne infrared spectroscopic analysis of emissions from a variety of flooded areas in the United States [6661-20]

R. Kroutil, Los Alamos National Lab. (USA); P. E. Lewis, National Geospatial Intelligence Agency (USA); M. J. Thomas, U.S. Environmental Protection Agency (USA); D. Miller, Northrop Grumman-TASC (USA); S. Shen, Aerospace Corp. (USA); T. Curry, U.S.

Environmental Protection Agency (USA)

$6661 \mathrm{OL}$ Chemical agent detection and identification with a hyperspectral imaging infrared sensor [6661-21]

V. Farley, M. Chamberland, P. Lagueux, A. Vallières, A. Villemaire, J. Giroux, Telops, Inc. (Canada)

6661 OM Measuring the modulation transfer function of imaging spectrometers at infinite focus with roof-line images [6661-22]

P. W. Nugent, J. A. Shaw, Montana State Univ. (USA); M. Kehoe, C. Smith, T. Moon,

R. Swanson, Resonon, Inc. (USA)

Author Index 
Downloaded From: https://www.spiedigitallibrary.org/conference-proceedings-of-spie on 26 Apr 2023

Terms of Use: https://www.spiedigitallibrary.org/terms-of-use 


\title{
Conference Committee
}

\author{
Symposium Chair
}

Zakya H. Kafafi, Naval Research Laboratory (USA)

Conference Chairs

Sylvia S. Shen, The Aerospace Corporation (USA)

Paul E. Lewis, National Geospatial Intelligence Agency (USA)

Conference Cochair

Robert T. Kroutil, Los Alamos National Laboratory (USA)

Program Committee

Christoph C. Borel, Ball Aerospace \& Technologies Corporation (USA)

Chein-I Chang, University of Maryland, Baltimore County (USA)

Thomas W. Cooley, Air Force Research Laboratory (USA)

Eustace L. Dereniak, College of Optical Sciences, The University of Arizona (USA)

Michael R. Descour, The University of Arizona (USA)

David B. Gillis, Naval Research Laboratory (USA)

Terrence S. Lomheim, The Aerospace Corporation (USA)

Anthony Ratowski, Air Force Research Laboratory (USA)

Luc Rochette, LR Tech (Canada)

John R. Schott, Rochester Institute of Technology (USA)

Winthrop Wadsworth, D\&P Instruments (USA)

Session Chairs

1 Spectrometer Design and Development

Paul E. Lewis, National Geospatial Intelligence Agency (USA)

2 Fourier Transform Spectrometer Design and Development

Luc Rochette, LR Tech (Canada)

3 Imaging Systems and Components

Robert T. Kroutil, Los Alamos National Laboratory (USA)

$4 \quad$ Spectral Data Analysis Techniques

John R. Schott, Rochester Institute of Technology (USA)

5 Spectral Methodologies and Applications

Sylvia S. Shen, The Aerospace Corporation (USA) 
Downloaded From: https://www.spiedigitallibrary.org/conference-proceedings-of-spie on 26 Apr 2023

Terms of Use: https://www.spiedigitallibrary.org/terms-of-use 